\title{
Indonesia's low concern for labour issues
}

\begin{abstract}
Purpose - This study advances explanations of the communication level of labour disclosures of Indonesian listed companies.

Design/methodology/approach - Year-ending 2007 Annual report disclosures of 223 Indonesia Stock Exchange (IDX) listed companies are analyzed. The Labour Practices and Decent Work Disclosure component of the 2006 Global Reporting Initiative (GRI) guidelines are used as the benchmark disclosure index checklist.

Findings - The results show a low level of voluntary disclosure (17.7\%). The highest level of communication is for issues related to Skills Management and Lifelong Learning Programs for Employees. Very few companies disclosed information about Health and Safety Committee and Agreements, and Salary of Men to Women. Statistical analysis reveals that government ownership and international operations are positively significant predictors of 'labour' communication. Isomorphic institutional theory partially explains the variability of these disclosures. Bigger companies also provide more Labour Practices and Decent Work Disclosures.

Research limitations/implications - The main implications of the findings are that Indonesian companies are not clearly communicating labour responsibility issues as a key precondition of Corporate Social Responsibility (CSR). They may be obfuscating some information to protect their image and reputation.

Originality/value - This paper provides insights into the disclosure practices of labour issues, a specific social disclosure theme which is rarely examined in prior literature, under the umbrella of institutional theory. The research also includes 'goal factor' to be tested as one of the independent variables.

Keywords Social accounting, Developing country, Communication, Institutional theory, Global Reporting Initiative

Paper type Research paper
\end{abstract}

Acknowledgements The authors would like to thank participants at the 2009 Accounting and Finance Association of Australia and New Zealand annual conference seminar and the 2009 Australasian Conference on Social and Environmental Accounting Research for their insightful comments on earlier versions of this paper. The authors are also grateful to two anonymous reviewers for their helpful comments on the paper.

\section{Introduction}

There are now fundamental and far-reaching changes in regulations relating to social reporting practices in Indonesia. From 7 December 2006, under the Indonesian Securities Supervisory Agency (BAPEPAM)'s regulation[1], all listed companies are required to

\footnotetext{
${ }^{1}$ This regulation is then strengthened by Act No. 40/2007 which requires limited companies in and/or related to the area of natural resources, regardless of whether they are listed or not, to perform social and environmental responsibility activities (Pemerintah Republik Indonesia, 2007). This act, which is effective from 16 August 2007, also requires all
} 
report any social responsibility activities in their annual reports (see BAPEPAM, 2006). These changes signal attention by the Indonesian government in regards to corporate social responsibility (CSR) activities and reporting practices. However, Utama (2008) argues that there are still problems in relation to the implementation of the new regulations as specific social activities items are not clearly delineated in those regulations. This brings into question the seriousness of the government on CSR regulation (see Kotijah, 2008). Given the lack of specifics and clarity in the regulations, the reporting practices of specific CSR items effectively remain voluntary. Thus, the extent of CSR reporting potentially varies across companies (Utama, 2008). This paper explores the actual level of disclosures by Indonesian companies.

CSR reporting has emerged as a serious research area since the mid-1970s in the business and particularly accounting literature (Neu et al., 1998). Previous studies on social accounting generally examine social issues in a broad context by looking holistically at a set of labour, human right, community, product responsibility, and environmental information (e.g. Mirfazli, 2008). In the last two decades, however, interest in CSR accounting has been overtaken by more specific focus on a subset of CSR reporting, namely environmental disclosure. According to Mathews (1997), the key factor driving such concern is the recognition that past and current financial accounting and disclosure mechanisms have failed to include issues which now threaten our planet.

More recently, there is also an observable trend in a growing number of studies focusing on another subset of CSR reporting, which is disclosure of companies' interaction with their workers (e.g. Vuontisjärvi, 2006; Brown et al., 2005), but there remains a literature gap in research on employees. According to Vuontisjärvi (2006), employees are critical components of CSR and therefore studies in this area are valuable. Johnston (2001) states that if a company does not perform high levels of CSR for its own employees it will not be able to pursue CSR activities for its outside environment (for example customers and local community). Given that CSR reporting is not clearly detailed in Indonesia, it is

limited companies (not only companies dealing with natural resources) to disclose social and environmental activities in their annual reports (Pemerintah Republik Indonesia, 2007). 
considered important to specifically examine the level of listed companies' CSR disclosures on labour issues[2] in this developing nation[3]. Labour related Global Reporting Initiative (GRI) social indicators are adopted as the disclosure index checklist for Labour Practices and Decent Work Disclosures examined in this study. Labour Practices and Decent Work Disclosures[4] encompass five main labour issues, which are Employment, Labor/Management Relations, Occupational Health and Safety, Training and Education, and Diversity and Equal Opportunity.

This paper is important for a number of reasons. Firstly, it provides insights into the disclosure practices on labour issues, a specific social disclosure theme. Secondly, it applies institutional theory, a relatively newer approach for explaining social disclosure practices (see Islam and Deegan, 2008). The use of this theory is potentially helpful and provides greater insights of Labour Practices and Decent Work Disclosure practices since theories previously used in CSR accounting literature such as stakeholder theory and legitimacy theory failed to fully explain the CSR reporting phenomenon (Milne and Patten, 2002; Deegan, 2009). Thirdly, it includes 'goal factor', a variable which is not commonly examined in previous disclosure studies, to be tested as one of the independent variables explaining labour disclosure practices. Finally, this study uses the latest 2006 version of GRI as the disclosure index checklist. This best represents the most internationally current stakeholder concerns on labour issues.

\section{Theoretical framework and hypotheses development}

Studies on CSR reporting, including those examining disclosures of labour issues, have adopted a variety of theories such as stakeholder theory (e.g. Cahaya et al., 2006) and legitimacy theory (e.g. Haniffa and Cooke, 2005). More recently, researchers have

\footnotetext{
2 In this nation, there is a distinctive gap in the power relationship between companies and their workers (see ILF, 2008). This dichotomy places workers in a far weaker position vis a vis the companies (ILF, 2008). Such disharmony highlights the need to investigate how Indonesian companies are socially responsible to their workers and how they then disclose information about this social responsibility.

${ }^{3}$ In addition to the issues of CSR related regulations, Indonesia's complex labour social problems are also of critical importance to many global multilateral organizations. This is evidenced by some studies undertaken by organizations like the World Bank and the International Labour Organization (ILO) on women workers' overtime compensation and child labour in Indonesia (see Pangestu and Hendytio, 1997; IDP, 2006). This further emphasizes the importance of choosing Indonesia as the country of study.

${ }^{4}$ LPDWD and labour disclosure practices are used interchangeably in this paper.
} 
employed institutional theory[5] (e.g. Amran and Siti-Nabiha, 2009). CSR accounting scholars (e.g. Milne and Patten, 2002; Amran and Devi, 2008; Deegan, 2009) now recommend focusing on this theory as it potentially provides greater insights of CSR reporting practices. Accordingly, this study adopts institutional theory as the underlying theoretical framework explaining labour disclosure practices in Indonesia.

Institutional theory is a branch of legitimacy theory which explains that organizations are faced with institutional pressures, and due to these pressures, organizations tend to become similar in their forms and practices (Perera, 2007; Islam and Deegan, 2008; Deegan, 2009). Institutional theory itself has two main dimensions: isomorphism and decoupling[6].(Deegan, 2009). In the context of this study, isomorphism can be seen as the process by which labour disclosure by an organization is influenced by institutional pressures (see Dillard et al. 2004) while decoupling is a situation in which labour disclosure is used by an organization to create an image which is different from that organization's actual activities, programs, and policies with its workers (see Deegan, 2009).

Results of past studies suggest that Indonesian companies communicate information about their CSR activities when they actually perform those activities and, in contrast, do not disclose CSR information when they do not have favourable CSR activities (Basalamah and Jermias, 2005). In Cahaya et al. (2006), for instance, it is suggested that Indonesian companies did not disclose some social issues such as anti-corruption programs because the management of the companies might be involved in corrupt activities. The focus of this study is exclusively on the process of organizations in undertaking labour disclosure practices, not on the relationship between companies'

\footnotetext{
${ }^{5}$ As stated by Deegan (2009), institutional theory has actually been developed within the management literature since the late 1970s (see for example Meyer and Rowan, 1977) and adopted in the accounting literature, but not specifically in the CSR reporting literature, since 1988 (see for example Covaleski and Dirsmith, 1988).

${ }^{6}$ One could argue that institutional theory has more than two dimensions. However, what is explicitly apparent from the literature is that there are only two main dimensions, which are isomorphism and decoupling (see Meyer and Rowan, 1977; DiMaggio and Powell, 1983; Dillard et al., 2004; Rodrigues and Craig, 2007; Islam and Deegan, 2008; Deegan, 2009). Moreover, it is stated by Rodrigues and Craig (2007) and Islam and Deegan (2008) that the key element of institutional theory is isomorphism. Accordingly, this study focuses the discussion on the two dimensions of isomorphism and decoupling, with a particular emphasis on the former one as it is adopted as the underlying theoretical framework of the study.
} 
labour disclosure practices and their actual performance. As such, this study adopts the isomorphic institutional dimension as the underlying theoretical framework.

As detailed by DiMaggio and Powell (1983), isomorphism consists of three processes: coercive isomorphism, mimetic isomorphism, and normative isomorphism[7] (DiMaggio and Powell, 1983). Coercive isomorphism refers to a situation in which organizations undertake institutional practices (e.g. labour disclosure practices) due to pressures from influential stakeholders (DiMaggio and Powell, 1983). Mimetic isomorphism refers to a situation in which organizations copy institutional practices of other organizations, often for competitive advantage reasons in terms of legitimacy (DiMaggio and Powell, 1983). Normative isomorphism refers to the pressures arising from group norms, such as managers to undertake particular institutional practices (DiMaggio and Powell, 1983; Deegan, 2009). In line with Amran and Devi (2007; 2008), this study examines labour disclosure practices by testing components of all three variants, as discussed in the following hypotheses development.

In Indonesia, creditors are a powerful and influential stakeholder group as listed companies rely extensively on creditors' funds (see Okuda and Take, 2005; Cahaya et al., 2008). Under Indonesia's Code of Good Corporate Governance, creditors are regarded as an important stakeholder group to whom companies must transparently provide information (Komite Nasional Kebijakan Governance, 2006). Based on their powerful position, creditors are therefore able to press companies to perform certain actions including the level of communication of CSR information (see Naser et al., 2006). Several prior studies document the significant effect of leverage on social disclosure practices (e.g. Naser et al., 2006). More particularly, a study by Alvarez (2007) shows that leverage has a significantly positive impact on human resource disclosures. In line with coercive isomorphism variant, this positive impact implies creditors' pressure on

\footnotetext{
7 These variants are phrased or termed differently by Scott (1995) as regulative, cognitive, and normative structures respectively. The meaning of these structures is essentially the same as DiMaggio and Powell's three isomorphic variants (see Larrinaga-Gonzales, 2007; Bebbington et al., 2009). In the literature, the three isomorphic variants are more popularly used and therefore this study does not adopt Scott's terms (see more detail discussions on DiMaggio and Powell's isomorphic institutional variants and Scott's structurally institutional variants in Larrinaga- González (2007)).
} 
companies to provide more labour information. To examine this possible pressure, this study hypothesizes that:

$\boldsymbol{H 1}$ There is a positive association between the leverage and the extent of voluntary Labour Practices and Decent Work Disclosures in the annual reports of IDX listed companies

In Indonesia, privatized government-owned companies are significantly influenced by the government's decisions due to government funding (Adnan and Nankervis, 2003). This condition places managers of these companies in a powerless position particularly to reject 'memos' from the government (Adnan and Nankervis, 2003). According to Amran and Devi (2008), this is where coercive isomorphism by the government comes into play. Given that the government now has regulations relating to CSR, and recently has also released programs specifically concerning the development of employee quality and productivity[8] (Depnakertrans, 2008), it can be argued that companies with government ownership are potentially pressured into disclosing more information on labour issues. The significant and generally positive relationship between government ownership and disclosure practices is well documented in the literature (e.g. Eng and Mak, 2003; Firer and Williams, 2005). Accordingly, a directional hypothesis is tested:

$\boldsymbol{H} 2$ There is a positive association between government ownership and the extent of voluntary Labour Practices and Decent Work Disclosures in the annual reports of IDX listed companies

DiMaggio and Powell (1983) state that companies within a similar industry tend to model themselves on similar companies that are more successful in securing legitimacy due to the adoption of a particular practice. For example, companies in high profile industries[9]

\footnotetext{
8 These employee development programs were released by the Indonesian Ministry of Manpower and Transmigration (see Depnakertrans, 2008). The programs include the development of work competence standard and certification systems for trained workers, establishments of competence-based training programs within companies, improvement of trainers' professionalism, and improvement of training facilities.

${ }^{9}$ High profile industries have been defined by Roberts (1992, p. 605) as those "with consumer visibility, a high level of political risk, and concentrated, intense competition". For the purpose of this study, the definition of high profile
} 
(e.g. mining) may disclose more information on occupational safety issues as their workers have a greater risk of injury during operations than might companies in low profile industries (e.g. retail). The significant relationship between industry type (particularly high versus low profile) and disclosure practices has been noted in a number of studies (see for example Hackston and Milne, 1996). To test the mimetic isomorphism of industry type, this study therefore hypothesizes:

$\boldsymbol{H} 3$ There is a positive association between high profile IDX listed companies and the extent of voluntary Labour Practices and Decent Work Disclosures in the annual reports

A company which also operates overseas competes with both domestic and overseas competitors. For these reasons, in terms of legitimacy and consistent with mimetic isomorphism tenets, the company will tend to follow successful competitors by copying particular practices. Such behaviour is more likely to occur when the regulatory environment is not certain, such as the current situation in Indonesia (see DiMaggio and Powell, 1983). Amran and Devi (2007) argue that a multinational company will follow existing regulation and culture of particular practices in overseas locations. In other words, to compete and obtain legitimacy globally, an internationally operating IDX listed company will imitate a particular CSR practice commonly undertaken overseas such as $S A 8000[10]$ and disclose that application in its annual report. In an Indonesian context, copying overseas practices may result in a higher level of labour disclosure practices (see Cahaya et al., 2008). As such, this study hypothesizes:

$\boldsymbol{H} 4$ There is a positive association between the presence of international operations, and the extent of voluntary Labour Practices and Decent Work Disclosures in the annual reports of IDX listed companies.

industries is made more specific with an emphasis on those having a high level of risk to workers, particularly risks of work related accident. The classification of IDX listed companies within high and low profile industries, is explained in Table I.

${ }^{10}$ SA8000 is a new management standard which has recently been applied by companies particularly in developed nations such as Japan concerning companies' accountability to their workers (SA8000, Standar Manajemen Baru, 2006). 
Amran and Devi (2007) argue that normative isomorphism pressures may occur when a firm has a stated goal related to CSR as such a goal reflects the way the company should behave. This argument can be applied in the context of labour disclosure practices where a company has an explicit and clearly stated goal related to the sustainable value of its employees. The sustainable value of employees in this study reflects the importance of workers as a critical component within a company whose continuous performance and skill development determines the continuity and the future of the company's operation. Managers may think that they should be socially responsible to their workers and accordingly disclose this responsibility in the annual report. This study thus predicts:

$\boldsymbol{H 5}$ There is a positive association between an explicit and clearly stated goal factor related to the sustainable value of employees and the extent of voluntary Labour Practices and Decent Work Disclosures in the annual reports of IDX listed companies

In the Indonesian corporate governance structure, commissioners, which is an equivalent term (and role) for non-executive directors[11], function as a check and balance mechanism to ensure that companies act in the best interest of shareholders and advising on the public presentation of the company's activities and performance (see Tricker 1984, p. 171). Such functions arguably enable commissioners, particularly the independent ones, to exert pressure on firms to disclose CSR information (see Haniffa and Cooke, 2005). In line with normative isomorphism and past studies (e.g. Haniffa and Cooke, 2005), it can thus be argued that companies with a greater composition of independent commissioners on the board will provide more labour disclosure practices. As such, a directional hypothesis is tested:

H6 There is a positive association between the proportion of independent commissioners and the extent of voluntary Labour Practices and Decent Work Disclosures in the annual reports of IDX listed companies

\footnotetext{
11 Under Act No. 40/2007, commissioners can be regarded equivalent to non-executive directors since they have the same responsibility as the supervisors and the advisors of executive directors (Pemerintah Republik Indonesia, 2007; Setyadi et al., 2007).
} 
This study examines company size, economic performance and age of business as control variables for the statistical analysis. Prior researchers suggest that these variables potentially influence the association between the independent and dependent variables in social disclosure studies and therefore they should be controlled (Cowen et al., 1987; Williams, 1999; Roberts, 1992). Bigger companies may disclose more social information because they interact with a greater number of stakeholders (Cahaya et al., 2008). It is also documented in Roberts (1992) that companies having satisfactory financial performance disclose more social information since they have sufficient financial support for doing so. Finally, more mature companies potentially disclose more social information as its history and reputation of involvement in CSR activities are entrenched (Roberts, 1992).

\section{Research methodology}

This study uses a quantitative positivist empirical research methodology to explain labour communication practices. A sample of 223 companies is selected from a population of 383 companies listed on the Indonesia Stock Exchange (IDX) in 2007 financial year (IDX, 2008). The selection of the companies is based on the availability of their 2007 annual reports in either the IDX website or the companies' websites. Data for all variables are collected from these annual reports [12].

The dependent variable in this study, namely Labour Practices and Decent Work Disclosures is measured by a disclosure index. Disclosure indices can be classified into weighted or unweighted indices (see Cooke, 1991). In a weighted disclosure index, particular disclosure items are given a higher score (when those items are disclosed) than the other disclosure items based on the perceived importance of those particular items (Cooke, 1991). For instance, information about injury during work could be given a score of (2) when this item is disclosed whereas another disclosed item such as the ratio of

\footnotetext{
12 The use of annual reports as the source of data is considered suitable for a disclosure study in a developing nation because other communication mediums are less used by most firms (Baker and Naser, 2000). An annual report itself is an official media of communication that must be provided by listed companies in Indonesia (BAPEPAM, 2008) and it generates a wide range of summarized relevant information about a company's performance (Coy et al., 2001).
} 
basic salary of male and female employees could be given a score of (1). This is because injury cases could be considered as having a relatively more dangerous impact on employees than the impact of salary.

In an unweighted index, each disclosure item is deemed equally important and therefore each item is awarded the same score when it is disclosed (Cooke, 1991; Meek et al., 1995). This disclosure index type is the one most often used in past disclosure studies (see for example Cooke, 1991; Hossain et al., 1995; Cahaya et al., 2008; Lim et al., 2007). An unweighted technique is considered to be far less subjective than a weighted technique and is more relevant to all companies (Chang et al., 1983; Cooke, 1991; Craig and Diga, 1998; Chavent et al., 2006; Abhayawansa and Abeysekera, 2009). It is therefore acknowledged in the literature that the unweighted approach has become the norm in disclosure studies (see Ahmed and Courtis, 1999). To be consistent with the past literature, this study adopts an unweighted technique for scoring each disclosure item.

To obtain the value of an unweighted index, the contents of each annual report are compared to the items listed on a checklist and coded as 1 or 0 , depending upon whether or not the content conforms to the items listed on the checklist (Meek et al., 1995). Thirteen voluntary GRI Labour Practices and Decent Work indicators are used in this study as the disclosure index checklist (see the details of the items in Appendix). A disclosure index for each company is then calculated as the ratio of total score awarded to the company divided by the maximum number of items that are applicable for the entity.

The main reason for adopting GRI performance indicators in this study is that they are the most widely accepted international reporting guidelines[13] which have a high international profile and focus primarily on the content of sustainability reporting (Fraser, 2005; Adams, 2004). These indicators have been developed through a dialogue-based process with global stakeholders from business, the investor, community, labor, civil society, accounting, academia, and others (Global Reporting Initiative, 2006; 2010).

13 Data from the GRI website reveals that there are now more than 1,000 organizations across the world using the GRI guidelines (see Global Reporting Initiative, 2010). 
Importantly, GRI indicators under the category of Labour Practices and Decent Work were developed based on internationally recognized labour standards such as United Nations Conventions and International labour Organization (ILO) Conventions (Global Reporting Initiative, 2006). It can thus be said that the use of GRI Labour Practices and Decent Work Disclosure items best represents the most internationally current stakeholder concerns on labour issues.

The measurement techniques for the explanatory variables are based on past studies' approaches (e.g. Hackston and Milne, 1996; Cahaya et al., 2008; Setyadi et al., 2007; Eng and Mak, 2003; Astami and Tower, 2006) and are summarized in Table I.

\section{[Take in Table I]}

\section{Descriptive results}

Results of the descriptive statistics[14] for the explanatory variables are summarized in Table II. Leverage of IDX listed companies' ranges from $0.5 \%$ to $400.58 \%$ with the mean of 58.12\%. The high mean is consistent with Cahaya et al.'s (2008) results, supporting the argument that companies in Indonesia rely extensively on creditors' funds. Interestingly, there is an increase in the independence of the board composition from 39\% in 2005 to about 44\% in 2007 (see Setyadi et al., 2007 for a comparison).

\section{[Take in Table II Here]}

For the control variables, it was found that total assets ranges widely from 566.67 million Rupiah to $319,085,590$ million Rupiah with a mean of 10,017,110 million Rupiah[15]. The descriptive statistics reveals a relatively low mean of return on assets (ROA), which is $3.92 \%$, with $9 \%$ of companies in the sample having a negative ROA. Nurhayati et al. (2006) argue that such a low ROA suggests that many Indonesian companies still suffer

\footnotetext{
14 Before performing the statistical analysis, data were independently verified by two Indonesian accounting academics. The purpose of this verification is to ensure the accuracy of data.

15 For illustrative purposes, 10,017 billion Rupiah equals to approximately 1,064 million Australian Dollars. This currency conversion is calculated based on the value of Rupiah against the Australian Dollar on 31 December 2007 determined by the Indonesian central bank (see Bank Indonesia, 2009).
} 
from the 1997 monetary crisis[16]. The results further show that the average age of the IDX listed company is 28 years old.

Most IDX listed companies (91\%) are fully privately owned while the other $9 \%$ are 'privatized' government-owned companies[17]. 44.4\% of sample companies are classified as high profile. It is also shown that $35.4 \%$ of sample companies operate internationally. This is consistent with Cahaya et al.'s (2008) finding that the frequency of internationally operating companies in Indonesia is lower than that of nationally operating companies. Finally, 52.9\% of sample companies clearly communicate goals related to the sustainable value of their employees.

The descriptive statistics of Labour Practices and Decent Work Disclosure practices is reported in Table III. Analysis shows that 19 companies did not provide any voluntary Labour Practices and Decent Work Disclosure items at all in their annual reports. The mean of labour disclosure level for all 223 sample companies is $17.7 \%$. Thus, on average, IDX listed companies disclose about two voluntary labour disclosure items (out of 13 items). This finding suggests that overall Labour Practices and Decent Work Disclosure practices of Indonesian listed companies are low.

\section{[Take in Table III Here]}

Figure I presents the variation of disclosure levels across the 13 voluntary Labour Practices and Decent Work Disclosure items[18]. It can be seen from this figure that

\footnotetext{
16 There appeared to be some recovery from the 1997 crises as evidenced by the increase in the average ROA of Indonesian listed companies from $2 \%$ in 2003 to $5.96 \%$ in 2004 (see Nurhayati et al., 2006; Cahaya et al., 2008). In 2007, however, as shown in Table II, the average ROA dropped to $3.92 \%$. This decline might be due to the weakening performance of finance industries in Indonesia during 2006 which still affects the financial performance of companies operating in those industries in 2007 (Daniel, 2007).

17 To date, 37 government-owned enterprises in Indonesia have been privatized through the capital market. Commentators argue that this privatization is undertaken because of pressures from foreign investors and organizations such as the World Bank and the International Monetary Fund (IMF) (Perampokan Harta Negara, 2008). They further posit that such a privatization negatively affects the welfare of Indonesian society as those companies' assets partially become the property of foreigners (Perampokan Harta Negara, 2008).

18 Although the third GRI Labour Practices and Decent Work indicator (LA3, Benefits provided to full- time employees) is excluded from this study, it is important to note that all 223 sample companies disclose this information in their annual reports. This shows IDX listed companies' compliance with PSAK No. 24. This item is not included in Figure I as it is excluded from the disclosure index checklist of this study.
} 
LA11, Programs for Skills Management and Lifelong Learning, is the most disclosed item (84.3\%). This information is generally reported in the Human Resource Development section of the annual reports. The very high level of disclosure of LA11 suggests that Indonesian companies see employee skill development programs as important for the sustainability of the companies' operation.

The second most disclosed item is LA13 Composition of Governance Bodies and Breakdown of Employees per Category according to Gender, Age group, Minority Group Membership, and Other Indicators of Diversity at 54.71\%. Further analysis reveals that the diversity indicator, other than gender, age, and minority group disclosed by the sample companies, is the education level of the employees such as masters, bachelor degree, or senior high school graduates. This information is generally reported in the Human Resource Development section of the annual reports, indicating that IDX listed companies strive to best provide a comprehensive picture on their employee profile.

\section{[Take in Figure I]}

In contrast, LA6, Percentage of Total Workforce in Joint Health and Safety Committees, is the least disclosed item at a miniscule $0.45 \%$. This is followed by LA9 Health and Safety Agreements with Trade Unions, and LA14 Salary of Men to Women both at $0.90 \%$. One possible explanation for the very low disclosure level of LA6, Percentage of Total Workforce in Joint Health and Safety Committees, and LA9, Health and Safety Agreements with Trade Unions, is that Indonesian companies are still predominantly not including their workers in negotiations and important leadership such as health and safety committees (ILF, 2008). Therefore, non-disclosure of LA6 and LA9 might be the best way to hide such an exclusion from the eyes of the annual report readers.

The very low disclosure level of items LA6 and LA9 also signals the weakness of labour unions in Indonesia as companies may not feel sufficiently pressured or influenced by unions to include their workers in formal health and safety joint committees and agreements. This is inconsistent with the arguments given by some scholars (see for 
example Rawling, 2006a; 2006b) who generally posit that labour unions have considerable power to influence companies' policies. It seems that, in this developing nation, labour unions such as SPSI (All Indonesian Labours' Union) are less influential and may be used as one of many feedback sources for the government in determining regulations about the relationship between employers and workers[19]. Thus, on the surface, Indonesian labour unions may look powerful but may be weaker than they appear.

There is an ongoing issue in relation to the salary of men to women. Under Act No. 13/2003[20] (Pemerintah Republik Indonesia, 2003), gender is not classified as one of the factors in formulating the structure and scales of wages. The act states that employers must give equal rights to male and female workers. However, in practice, female workers in Indonesia receive lower wages than male workers, particularly in manufacturing industries (Bennington and Habir, 2003). Gender may well be used by companies to determine the amount of wages for their workers and therefore they strategically choose to be less than transparent in disclosing information on compensation arrangements for LA14 Salary of Men to Women.

\section{Predictors of voluntary Labour Practices and Decent Work Disclosures}

The six hypotheses were tested by using multiple regression techniques[21]. According to Coakes and Steed (2007), complete regression is appropriate for examining the association between the whole set of predictors and the dependent variable. The results of this regression are summarized in Table IV.

\footnotetext{
19 In Indonesia, labour unions, which are represented by SPSI, look influential since they are involved in the issuance of many joint decrees such as Act No.3/1992 about the Workers' Social Security Program with the Indonesian government (Tambunan and Purwoko, 2002).

20 Act No. 13/2003 is the Indonesian government act which regulates manpower issues.

${ }^{21}$ Classical assumptions of multiple regression (multicollinearity, normality, linearity, outliers, and homoscedasticity (see Hair et al., 1998)) have been checked and it was found that the assumptions of normality and homoscedasticity were not initially met. Data of key continuous variables were therefore transformed into natural logarithm. After this transformation, the normality assumption was met but heteroscedasticity still existed. According to Tabachnick and Fidell (2001), heteroscedasticity is not fatal to a multiple regression analysis therefore post-transformation-regression results are used as the hypotheses test in this study. Tabachnick and Fidell (2001) further argue that, in a multiple regression, heteroscedasticity does not invalidate the results although it may weaken them. Importantly, if the normality assumption, which is the main regression assumption, is met as in this study, the relationship between variables can be considered homoscedastic (Tabachnick and Fidell, 2001).
} 


\section{[Take in Table IV]}

From Table IV, it can be seen that the regression model is highly significant (p-value 0.000 ). The value of adjusted R-square is 0.384 . The variation of voluntary labour disclosure practices is explained by the variation of two highly significant predictors. These are government ownership and international operations. Company size is also significant but at a moderate level. The coefficients of these three variables are positive, supporting the argument previously presented in this paper which posits that there are positive associations between voluntary Labour Practices and Decent Work Disclosure practices and government ownership (Hypothesis 2), the presence of international operations (Hypothesis 4) and company size (control variable). The other hypothesized variables (leverage, industry type, explicit and clearly stated goal related to the sustainable value of employees, and independence of board) and the control variables (economic performance and age of business) were not found to be significant.

\section{Discussion and conclusion}

In summary, whilst almost all of the sample companies (91.5\%) communicated at least one item, there is an overall low level of labour disclosure practices (17.7\%) by IDX listed companies. This leads to concerns about the level of under-reporting that is occurring in Indonesia in relation to labour and work practices. Such under-reporting might be a reflection of the lack of details in the legislation regarding CSR reporting.

The results imply that Indonesian companies do not really see labour responsibility issues as a key precondition of CSR performance and reporting. This is evidenced by the low overall disclosure practices as well as the selective focusing on only a few particular items whilst ignoring other important items. Indonesian companies might be concealing some information to protect their image and reputation. Such practices thus signal that institutional pressures on labour disclosure in an Indonesian setting are low. 
This study finds that leverage does not significantly influence the level of voluntary labour disclosure practices although, in Indonesia, creditors are influential. This insignificant result is consistent with Cormier and Gordon (2001). This may imply that the coercive pressure of creditors on Indonesian companies does exist but not in terms of the provision of labour disclosure in the annual reports.

An important finding of this study is the positively significant effect of government ownership on voluntary labour disclosure practices. This outcome is consistent with Firer and Williams (2005) and Eng and Mak (2003), showing that the coercive pressure of the Indonesian government on companies to disclose labour issues does exist. According to Adnan and Nankervis (2003), there is a strong influence by the government on government owned enterprises, including 'privatized' government-owned companies, because most members of the board of directors in such companies are high ranking government officials. This finding implies that the Indonesian government is striving to deal seriously with CSR matters by at least compelling companies through its officials sitting on those companies' boards to perform and communicate good CSR activities.

Industry type variable is found to be statistically insignificant. There is uniformity of labour communication across high and low industry groupings. This finding is consistent with Brown et al., (2005) and Cahaya et al., (2008). This insignificant association is possibly explained by the argument that mimetic isomorphism copying practices may occur in a more specific industry classification such as within each of the nine IDX classifications (e.g. agriculture, mining, basic industry and chemicals).

The presence of international operations is significant in a positive direction. This is consistent with Cahaya et al. (2008) and supports Hypothesis 4 that companies with international operations provide more voluntary labour disclosure practices. One explanation for this positive relationship is that Indonesian companies' overseas competitors are socially responsible to their employees and disclose any actions 
regarding this responsibility in their annual reports[22]. In line with the mimetic isomorphism of institutional theory, to compete with foreign competitors, Indonesian companies then copy their labour reporting practices. This finding therefore implies that companies in Indonesia need to seriously consider undertaking good social responsibility to their employees and disclose this responsibility in their annual reports to better survive in a global market.

The explicit communication of a goal related to the sustainable value of employees is not a significant predictor of voluntary labour disclosure practices. This is at odds with the study by Amran and Devi (2007). One reason may be a problem of categorization, given the stakeholder groups mentioned in the stated goal are not always specifically focused on employees. Instead the stated overarching goal may be used as a symbol to project a good image to annual report readers.

The independent composition of board is not a significant predictor of voluntary labour disclosure practices, a finding which is consistent with a number of previous disclosure studies such as Nurhayati et al., (2006). The lack of supervision effectiveness of Indonesian commissioners might best explain this finding (World Bank, 2005).

Only one control variable, which is company size, is statistically significant but at a moderate level. One possible explanation is that bigger companies interact with a greater number of stakeholders (see Cahaya et al., 2008) with interests in different labour issues. To satisfy these interests, the companies perform a number of different labour related CSR activities and disclose these activities in their annual reports, resulting in a higher level of labour disclosure. As such, bigger companies in Indonesia more explicitly manage the relationship with their stakeholders through the implementation of good labour related CSR activities.

\footnotetext{
22 The social responsibility activities may include the application of $S A 8000$ (refer theoretical framework section of this paper).
} 
Overall, Indonesian listed companies voluntarily provide a low level of labour practices and decent work information. This is concerning given the new regulatory changes introduced into Indonesia for all listed companies to report social responsibility activities in their annual reports (see BAPEPAM, 2006). This study finds that the variability of Labour Practices and Decent Work Disclosures is partially explained by isomorphic institutional theory, particularly by its coercive and mimetic variants. This study thus provides important contributions to the literature by offering additional knowledge regarding the positively significant impacts of government ownership, international operations and company size on the level of labour disclosure practices in this developing nation.

The lack of disclosure may also be explained by the lack of specific details provided in the Indonesian legislation or by a lag affect in implementing the requirements, with both aspects being recommended for future research. Additionally, it may be explained by the lack of effective enforcement by the government. As indicated in the literature, the regulatory enforcement in Indonesia is weak (see Bennington and Habir, 2003; Setyadi et al., 2007). This therefore raises questions: Are the Indonesian government and their securities regulator BAPEPAM serious in regulating CSR issues? Are they choosing strategic inaction with the regulations so that their CSR regulatory practices look good in front of the eyes of international audiences? Or, do they lack a good understanding of CSR practices which has resulted in unclear regulation lacking details? These questions are all areas that need further exploration.

As with most research, this study has limitations. Firstly, only companies having a direct government ownership is considered as those having a proportion of government ownership. This is because Indonesian listed companies usually do not clearly disclose whether or not they indirectly belong to the government through government-owned enterprises in their annual reports. The direct ownership itself is arguably appropriate since it clearly reflects direct control and pressure of the government on companies through their representatives in the board of directors to undertake particular practices (Amran and Devi, 2008). Secondly, only two influential stakeholder groups, creditors and 
the government, are addressed in the hypotheses. Other influential stakeholder groups such as 'interest groups' are also potentially able to pressure companies to disclose labour information. Future research including other independent variables such as media exposure[23] could be undertaken particularly to provide more insights into the Labour Practices and Decent Work Disclosure practices in this developing country.

\section{References}

Abhayawansa, S. and Abeysekera, I. (2009), "Intellectual capital disclosure from sellside analyst perspective", Journal of Intellectual Capital, Vol. 10 No. 2, pp. 294 306.

Adams, C.A. (2004), "The ethical, social \& environmental reporting: performance portrayal gap", Accounting, Auditing \& Accountability Journal, Vol. 17 No. 5, pp. 731-757.

Adnan, Z. and Nankervis, A. (2003), "Chapter 6: management in Indonesia", in Chatterjee, S. and Nankervis, A. (Ed.), Understanding Asian Management: Transition and Transformation, Vineyard Publishing, Guildford, pp. 195-222.

Ahmed, K. and Courtis, J.K. (1999), "Associations between corporate characteristics and disclosure levels in annual reports: a meta-analysis", The British Accounting Review, Vol. 31 No. 1, pp. 35-61.

Alvarez, M. (2007), "Corporate firm characteristics and human resource disclosure in Spain", paper presented at the Thirtieth Annual Congress of the European Accounting Association, Lisbon, 25-27 April.

Amran, A. and Devi, S.S. (2007), "Corporate social reporting in Malaysia: a mixed method approach", paper presented at the Fifth Asia Pacific Interdisciplinary Research in Accounting Conference, Auckland, 6-7 July.

Amran, A. and Devi, S.S. (2008), "The impact of government and foreign affiliate influence on corporate social reporting: the case of Malaysia", Managerial Auditing Journal, Vol. 23 No. 4, pp. 386-404.

Amran, A. and Siti-Nabiha, A.K. (2009), "Corporate social reporting in Malaysia: a case of mimicking the West or succumbing to local pressure", Social Responsibility Journal, Vol. 5 No. 3, pp. 358-375.

Astami, E.W. and Tower, G. (2006), "Accounting-policy choice and firm characteristics in the Asia Pacific region: an international empirical test of costly contracting theory", The International Journal of Accounting, Vol. 41 No. 1, pp. 1-21.

Baker, A. and Naser, K. (2000), "Empirical evidence on corporate social disclosure (CSD) practices in Jordan", International Journal of Commerce \& Management, Vol. 10 No. 3/4, pp. 18-34.

23 According to Cormier et al. (2005), media exposure can reflect the pressure from a wide range of influential stakeholders such as labour unions, suppliers, and citizens. 
Bank Indonesia. (2009), "Kurs uang kertas asing", available at: http://www.bi.go.id/web/id/Moneter/Kurs+Bank+Indonesia/Kurs+Uang+Kertas+ Asing/ (accessed 12 February 2009).

BAPEPAM. (2006), "Salinan keputusan Ketua Badan Pengawas Pasar modal dan Lembaga Keuangan Nomor: kep-134/b1/2006 tentang kewajiban penyampaian laporan tahunan bagi emiten atau perusahaan public", available at: http://www.bapepam.go.id/pasar_modal/regulasi_pm/peraturan_pm/X/X.K.6.pdf. (accessed 24 March 2008).

BAPEPAM. (2008), available at: http://bapepam.go.id (accessed 25 July 2008).

Basalamah, A.S. and Jermias, J. (2005), "Social and environmental reporting and auditing in Indonesia", Gadjah Mada International Journal of Business, Vol. 7 No. 1, pp. 109-127.

Bebbington, J., Higgins, C. and Frame, B. (2009), "Initiating sustainable development reporting: evidence from New Zealand", Accounting, Auditing \& Accountability Journal, Vol. 22 No. 4, pp. 588 - 625.

Bennington, L. and Habir, A.D. (2003), "Human resource management in Indonesia", Human Resource Management Review, Vol. 13 No. 3, pp. 373-392.

Brown, A.M., Tower, G. and Taplin, R. (2005), "Human resources disclosures in the annual reports of Pacific island countries' entities", Asia Pacific Journal of Human Resources, Vol. 43 No. 2, pp. 252-272.

Cahaya, F.R., Porter, S.A. and Brown, A.M. (2006), "Nothing to report? motivations for non-disclosure of social issues by Indonesian listed companies", The Journal of Contemporary Issues in Business and Government, Vol. 12 No. 1, pp. 43-61.

Cahaya, F.R., Porter, S.A. and Brown, A.M. (2008), "Social disclosure practices by Jakarta Stock Exchange listed entities", Journal of the Asia-Pacific Centre for Environmental Accountability, Vol. 14 No. 1, pp. 2-11.

Chang, L.S., Most, K.S. and Brain, C.W. (1983), "The utility of annual reports: an international study", Journal of International Business Studies, Vol. 14 No. 1, pp. 63-84.

Chavent, M., Ding, Y., Fu, L., Stolowy, H. and Wang, H. (2006), "Disclosure and determinants studies: an extension using the divisive clustering method (DIV)", European Accounting Review, Vol. 15 No. 2, pp. 181 - 218.

Coakes, S. and Steed, L. (2007), SPSS: Analysis Without Anguish: Version 14.0 for Windows, John Wiley \& Sons Australia, Milton.

Cooke, T.E. (1991), "An assessment of voluntary disclosure in the annual reports of Japanese corporations", The International Journal of Accounting, Vol. 26 No. 3, pp. 147-189.

Cormier, D. and Gordon, I.M. (2001), "An examination of social and environmental reporting strategies", Accounting, Auditing \& Accountability Journal, Vol. 14 No. 5, pp. 587-616.

Cormier, D., Magnan, M. and Van Velthoven, B. (2005), "Environmental disclosure quality in large German companies: economic incentives, public pressures or institutional conditions?", European Accounting Review, Vol. 14 No. 1, pp. 3-39.

Covaleski, M.A. and Dirsmith, M.W. (1988), "An institutional perspective on the rise, social transformation, and fall of a university budget category", Administrative Science Quarterly, Vol. 33 No. 4, pp. 562-587. 
Cowen, S.S., Ferreri, L.B. and Parker, L.D. (1987), "The impact of corporate characteristics on social responsibility disclosure: a typology and frequency-based analysis", Accounting, Organizations and Society, Vol. 12 No. 2, pp. 111-122.

Coy, D., Fischer, M. and Gordon, T. (2001), "Public accountability: A new paradigm for college and universities annual reports", Critical Perspectives on Accounting, Vol. 12 No. 1, pp. 1-31.

Craig, R. and Diga, J. (1998), "Corporate accounting disclosure in ASEAN", Journal of International Financial Management \& Accounting, Vol. 9 No. 3, pp. 246-274.

Daniel, W. (2007), "Kinerja multifinance 2006 paling rendah dalam 5 tahun", available at: $\quad$ http://www.detiksport.com/read/2007/07/31/163903/811586/6/kinerjamultifinance-2006-paling-rendah-dalam-5-tahun (accessed 23 January 2009).

Deegan, C. (2009), Financial Accounting Theory, 3rd ed, McGraw-Hill, North Ryde.

Depnakertrans. (2008), "Program kerja tahun 2007 Depnakertrans", available at: http://www.nakertrans.go.id/tentang.html,program (accessed 28 May 2008).

Dillard, J.F., Rigsby, J.T. and Goodman, C. (2004), "The making and remaking of organization context: duality and the institutionalization process", Accounting, Auditing \& Accountability Journal, Vol. 17 No. 4, pp. 506-542.

DiMaggio, P.J. and Powell, W.W. (1983), "The iron cage revisited: institutional isomorphism and collective rationality in organizational fields", American Sociology Review, Vol. 48 No. 2, pp. 146 - 160.

Eng, L.L. and Mak, Y.T. (2003), "Corporate governance and voluntary disclosure", Journal of Accounting and Public Policy, Vol. 22 No. 4, pp. 325-345.

Firer, S. and Williams, S.M. (2005), "Firm ownership structure and intellectual capital disclosures", South African Journal of Accounting Research, Vol. 19 No. 1, pp. 118.

Fraser, B.W. (2005), "Corporate social responsibility”, Internal Auditor, Vol. 62 No. 1, 43-47.

Friedland, R. and Alford, R.R. (1991), "Bringing society back in: symbols, practices, and institutional contradictions", in Powell, W.W. and DiMaggio, P.J. (Ed.), The New Institutionalism in Organizational Analysis, The University of Chicago Press, Chicago, pp. 232-263.

Global Reporting Initiative. (2006), "Sustainability reporting guidelines", available at: http://www.globalreporting.org/NR/rdonlyres/ED9E9B36-AB54-4DE1-BFF25F735235CA44/0/G3 GuidelinesENU.pdf (accessed 23 March 2008).

Global Reporting Initiative. (2010), available at: http://www.globalreporting.org (accessed 9 January 2010).

Hackston, D. and Milne, M.J. (1996), "Some determinants of social and environmental disclosures in New Zealand companies", Accounting, Auditing \& Accountability Journal, Vol. 9 No. 1, pp. 77-108.

Hair, J.F., Anderson, R.E., Tatham, R.L. and Black, W.C. (1998), Multivariate Data Analysis, 5th ed, Prentice-Hall, New Jersey.

Haniffa, R.M. and Cooke, T.E. (2005), "The impact of culture and governance on corporate social reporting", Journal of Accounting and Public Policy, Vol. 24 No. 5, pp. 391-430. 
Hossain, M., Perera, M. and Rahman, A. (1995), "Voluntary disclosure in the annual reports of New Zealand companies", Journal of International Financial Management and Accounting, Vol. 6 No. 1, pp. 69-87.

IAI. (2007), Standar Akuntansi Keuangan per 1 September 2007, Penerbit Salemba Empat, Jakarta.

IDP. (2006), "Penelitian ILO tentang perilaku terhadap buruh anak dan pendidikan di Indonesia", available at: http://www.idpeurope.org/eenet/newsletter2_Indonesia/page11.php (accessed 19 June 2006).

IDX. (2008), available at: http://www.idx.co.id/ (accessed 15 March 2008).

ILF. (2008), available at: http://www.buruhindonesia.com (accessed 3 July 2008).

Islam, M.A. and Deegan, C. (2008), "Motivations for an organisation within a developing country to report social responsibility information: evidence from Bangladesh", Accounting, Auditing \& Accountability Journal, Vol. 21 No. 6, pp. 850 - 874.

Johnston, P. (2001), "Corporate responsibility in employment standards in a global knowledge economy", in Zadek, S., Hojensgard, N. and Raynard, P. (Ed.), Perspectives on The New Economy of Corporate Citizenship, The Copenhagen Centre, Copenhagen, pp. 43-47.

Komite Nasional Kebijakan Governance. (2006), "Pedoman umum good corporate governance Indonesia", available at: http://www.bapepam.go.id/pasar_modal/publikasi_pm/info_pm/Pedoman\%20GC G\%20Indonesia\%202006.pdf (accessed 6 July 2008).

Kotijah, S. (2008), "Menggugat corporate social responsibility", available at: http://gagasanhukum.wordpress.com/2008/08/14/menggugat-corporate-socialresponsibility/ (accessed 25 October 2009).

Larrinaga-González, C. (2007), "Insights from neoinstitutional theory", in Unerman, J., Bebbington, J. and O'Dwyer, B. (Ed.), Sustainability Accounting and Accountability, Routledge, London, pp. 150-167.

Lim, S., Matolcsy, Z. and Chow, D. (2007), "The association between board composition and different types of voluntary disclosure", European Accounting Review, Vol. 16 No. 3, pp. 555-583.

Mathews, M.R. (1997), "Towards a mega-theory of accounting", Asia-Pacific Journal of Accounting, Vol. 4 No. 2, pp. 273-289.

Meek, G.K., Roberts, C.B. and Gray, S.J. (1995), "Factors influencing voluntary annual report disclosures by U.S., U.K. and continental European multinational corporations", Journal of International Business Studies, Vol. 26 No. 3, pp. 555572.

Meyer, J. and Rowan, B. (1977), "Institutional organizations: formal structures as myths and ceremonies", American Journal of Sociology, Vol. 83 No. 2, pp. 840-863.

Milne, M.J. and Patten, D. (2002), "Securing organizational legitimacy: an experimental decision case examining the impact of environmental disclosures", Accounting, Auditing \& Accountability Journal, Vol. 15 No. 3, pp. 372-405.

Mirfazli, E. (2008), "Evaluate corporate social responsibility disclosure at annual report companies in multifarious group of industry members of Jakarta Stock Exchange (JSX), Indonesia”, Social Responsibility Journal, Vol. 4 No. 3, pp. 388 - 406. 
Naser, K., Al-Hussaini, A., Al-Kwari, D. and Nuseibeh, R. (2006), "Determinants of corporate social disclosure in developing countries: the case of Qatar", Advances in International Accounting, Vol. 19, pp. 1-23.

Neu, D., Warsame, H. and Pedwell, K. (1998), "Managing public impressions: environmental disclosures in annual reports", Accounting, Organizations and Society, Vol. 23 No. 3, pp. 265-282.

Nurhayati, R. (2005), "The determinants of the level of natural environmental disclosures of JSX listed entities", unpublished Master thesis, Curtin University of Technology, Perth.

Nurhayati, R., Brown, A. and Tower, G. (2006), "Understanding the level of natural environmental disclosures by Indonesian listed companies", Journal of the Asia Pacific Centre for Environmental Accountability, Vol. 12 No. 3, pp. 4-11.

Okuda, H. and Take, Y. (2005), "Economic reforms and financing structure of Indonesian listed companies after the Asian crisis: corporate finance issues and the solutions", Japan Bank for International Cooperation Review, Vol. 12, pp. 131.

Pangestu, M. and Hendytio, M. (1997), "Survey responses from women workers in Indonesia's textile, garment, and footwear industries", available at: http://www.worldbank.org/html/dec/Publications/Workpapers/WPS1700series/wp s1755/wps1755.pdf (accessed 17 January 2006).

Pemerintah Republik Indonesia. (2003), "Undang-undang Republik Indonesia Nomor 13 tahun 2003 tentang ketenagakerjaan", available at: http://www.nakertrans.go.id/uploads/doc/perundangan/417815068485219144c77 b.pdf (accessed 26 January 2009).

Pemerintah Republik Indonesia. (2007), "Undang-undang Republik Indonesia Nomor 40 tahun 2007 tentang perseroan terbatas", available at: http://www.djkn.depkeu.go.id/download/Peraturan/Undang-Undang/UU402007.pdf. (accessed 19 March 2008).

Perampokan Harta Negara. (2008), available at: $\underline{\text { http://jurnal- }}$ ekonomi.org/2008/02/06/bom-privatisasi-indonesia-2008/ (accessed 3 June 2009).

Perera, H. (2007), "The international and cultural aspects of social accounting", in Gray, R. and Guthrie, J. (Ed.), Social Accounting, Mega Accounting and Beyond: A Festschrift in Honour of M.R. Mathews, CSEAR Publishing, St. Andrews, pp. 9199.

Rawling, M. (2006a), "Australian trade unions as shareholder activists: the rocky path towards corporate democracy", Sydney Law Review, Vol. 28 No. 2, pp. 227-258.

Rawling, M. (2006b), "Satisfying employee and shareholder demands in an era of union shareholder activism", Keeping Good Companies, Vol. 58 No. 2, pp. 104-108.

Roberts, R.W. (1992), "Determinants of corporate social responsibility disclosure: an application of stakeholder theory", Accounting, Organizations and Society, Vol. 17 No. 6, pp. 595-612.

Rodrigues, L.L. and Craig, R. (2007), “Assessing international accounting harmonization using Hegelian dialectic, isomorphism and Foucault", Critical Perspectives on Accounting, Vol. 18 No. 6, pp. 739-757. 
SA8000, Standar Manajemen Baru, (2006), available at: http://www.portalhr.com/majalah/edisisebelumnya/strategi/1id341.html (accessed 8 July 2008).

Scott, W. R. (1995), Institutions and Organizations, SAGE, Beverly Hills.

Setyadi, A., Rusmin, Brown, A. and Tower, G. (2007), "Following the rules? a mixed message from Indonesia", The Journal of Contemporary Issues in Business and Government, Vol. 13 No. 1, pp. 87-104.

Tabachnick, B.G., and Fidell, L.S. (2001), Using Multivariate Statistics, 4th ed, Pearson Education Company, Boston.

Tambunan, T.H.T. and Purwoko, B. (2002), "Social protection in Indonesia", in Adam, E., Hauff, M. and John, M. (Ed.), Social Protection in Southeast and East Asia, Friedrich Ebert Stiftung, The Plaza Singapore, pp. 21-73.

Tricker, R.I. (1984), Corporate Governance: Practices, Procedures and Powers in British Companies and Their Boards of Directors, Gower Publishing Company, Hampshire.

Utama, S. (2008), "Evaluasi infrastruktur pendukung pelaporan tanggung jawab sosial dan lingkungan di Indonesia", available at: http://www.ui.edu/post/evaluasiinfrastruktur-pendukung-pelaporan-tanggung-jawab-sosial-dan-lingkungan-diindonesia-id.html?UI=0e7f723ba866af9ed3db5006261670d5 (accessed 21 March 2008).

Vuontisjärvi, T. (2006), "Corporate social reporting in the European context and human resource disclosures: an analysis of Finnish companies", Journal of Business Ethics, Vol. 69 No. 4, pp. 331-354.

Williams, S.M. (1999), "Voluntary environmental and social accounting disclosure practices in the Asia Pacific region: an international empirical test of political economy theory", The International Journal of Accounting, Vol. 34 No. 2, pp. 209-238.

World Bank. (2005), Report on The Observance of Standards and Codes, Republic of Indonesia, The World Bank, Washington, DC.

\section{Appendix. The 2006 Global Reporting Initiative (GRI) labour practices and decent work indicators}

\begin{tabular}{|l|l|l|l|}
\hline \multicolumn{2}{|c|}{ Category } & \multicolumn{1}{|c|}{$\begin{array}{c}\text { GRI } \\
\text { code }\end{array}$} & \\
\hline A.1. & Employment ${ }^{\text {a }}$ & LA1 & Total workforce by employment type, employment contract, and region. \\
\cline { 3 - 4 } & & LA2 & $\begin{array}{l}\text { Total number and rate of employee turnover by age group, gender, and } \\
\text { region. }\end{array}$ \\
\cline { 3 - 4 } & & LA3 & $\begin{array}{l}\text { Benefits provided to full-time employees that are not provided to temporary } \\
\text { or part-time employees, by major operations. }\end{array}$ \\
\hline A.2. & $\begin{array}{l}\text { Labor/Management } \\
\text { Relations }\end{array}$ & LA4 & Percentage of employees covered by collective bargaining agreements. \\
\cline { 3 - 5 } & & LA5 & $\begin{array}{l}\text { Minimum notice period(s) regarding operational changes, including whether } \\
\text { it is specified in collective agreements. }\end{array}$ \\
\hline A.3. & $\begin{array}{l}\text { Occupational } \\
\text { Health and Safety }\end{array}$ & LA6 & $\begin{array}{l}\text { Percentage of total workforce represented in formal joint management- } \\
\text { worker health and safety committees that help monitor and advise on } \\
\text { occupational health and safety programs. }\end{array}$ \\
\cline { 3 - 4 } & & LA7 & Rates of injury, occupational diseases, lost days, and absenteeism, and \\
\hline
\end{tabular}




\begin{tabular}{|c|c|c|c|}
\hline & & & number of work related fatalities by region. \\
\hline & & LA8 & $\begin{array}{l}\text { Education, training, counseling, prevention, and risk-control programs in } \\
\text { place to assist workforce members, their families, or community members } \\
\text { regarding serious diseases. }\end{array}$ \\
\hline & & LA9 & Health and safety topics covered in formal agreements with trade unions. \\
\hline \multirow[t]{3}{*}{ A.4. } & \multirow{3}{*}{$\begin{array}{l}\text { Training and } \\
\text { Education }\end{array}$} & LA10 & Average hours of training per year per employee by employee category. \\
\hline & & LA11 & $\begin{array}{l}\text { Programs for skills management and lifelong learning that support the } \\
\text { continued employability of employees and assist them in managing career } \\
\text { endings. }\end{array}$ \\
\hline & & LA12 & $\begin{array}{l}\text { Percentage of employees receiving regular performance and career } \\
\text { development reviews. }\end{array}$ \\
\hline \multirow[t]{2}{*}{ A.5. } & \multirow[t]{2}{*}{$\begin{array}{l}\text { Diversity and } \\
\text { Equal Opportunity }\end{array}$} & LA13 & $\begin{array}{l}\text { Composition of governance bodies and breakdown of employees per } \\
\text { category according to gender, age group, minority group membership, and } \\
\text { other indicators of diversity. }\end{array}$ \\
\hline & & LA14 & Ratio of basic salary of men to women by employee category \\
\hline
\end{tabular}

Source: Global Reporting Initiative (2006).

a) If an indicator has several subparts, a score of 1 will be awarded when any of the subparts is disclosed. This is due to the possible scarcity of information within the annual report. In LA1, for example, a score of 1 will be awarded if the company discloses any of the three subparts: total workforce by employment type, employment contract or region b) LA3 is excluded from the disclosure index checklist of this study because, under PSAK No. 24, this item is considered as a mandatory item (see IAI, 2007). Accordingly, in the main statistical analysis, only thirteen items are used to measure Labour Practices and Decent Work Disclosure practices.

\section{Table I Measurement technique of the independent and control variables}

\begin{tabular}{|c|c|c|c|c|}
\hline $\begin{array}{l}\text { Isomorphic } \\
\text { process }\end{array}$ & $\begin{array}{l}\text { Independent } \\
\text { variables }\end{array}$ & $\begin{array}{c}\text { Control } \\
\text { variables }\end{array}$ & Measurement & Type of data \\
\hline Coercive & Leverage & & Total liabilities divided by total assets & Continuous \\
\hline isomorphism & $\begin{array}{l}\text { Government } \\
\text { ownership }\end{array}$ & & $\begin{array}{l}1=\text { there is a proportion of government ownership } \\
0=\text { otherwise }\end{array}$ & Categorical \\
\hline \multirow[t]{3}{*}{$\begin{array}{l}\text { Mimetic } \\
\text { isomorphism }\end{array}$} & Industry type $^{\mathrm{a}}$ & & $\begin{array}{l}1=\text { high profile industry } \\
0=\text { low profile industry }\end{array}$ & Categorical \\
\hline & $\begin{array}{l}\text { International } \\
\text { operations }\end{array}$ & & $\begin{aligned} 1= & \text { Yes-Have material foreign sales or a foreign } \\
& \text { subsidiary or a foreign branch office }\end{aligned}$ & Categorical \\
\hline & & & $\begin{aligned} 0= & \text { No material foreign sales, foreign subsidiaries } \\
& \text { or foreign branch offices }\end{aligned}$ & \\
\hline \multirow[t]{6}{*}{$\begin{array}{l}\text { Normative } \\
\text { isomorphism }\end{array}$} & $\begin{array}{l}\text { Explicit and clearly } \\
\text { stated goal related } \\
\text { to the sustainable }\end{array}$ & & $\begin{array}{l}1=\text { the company has clearly communicated } \\
\text { goals/missions related to sustainable value of its } \\
\text { employees }\end{array}$ & Categorical \\
\hline & value of employees & & 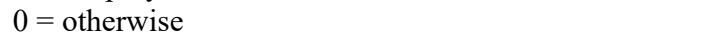 & \\
\hline & $\begin{array}{l}\text { Independence of } \\
\text { board }\end{array}$ & & Percentage of independent commissioners in the board & Continuous \\
\hline & & Company size ${ }^{b}$ & Log of total assets & Continuous \\
\hline & & $\begin{array}{l}\text { Economic } \\
\text { performance }\end{array}$ & Return on Assets (ROA) : 2 year average & Continuous \\
\hline & & Age of business & Number of years from inception & Continuous \\
\hline
\end{tabular}

Source: Original table

a Consistent with Nurhayati (2005), IDX's official industry classification, which consists of nine industries, is reclassified into the high-low coding. Seven industries namely agriculture, mining, basic industry and chemicals, miscellaneous industry, consumer goods industry, property and real estate, and infrastructure, utilities and 
transportation are classified as high profile industries whereas the other two, finance and trade, services and investment, are classified as low profile industries.

b Company size was initially measured by total assets but finally logged to reduce skewness (Tabachnick and Fidell, 2001).

\section{Table II Descriptive statistics of the independent and control variables}

\begin{tabular}{|c|c|c|c|c|c|c|}
\hline \multicolumn{7}{|c|}{ Panel A: Continuous variables } \\
\hline Variable & Measurement & Minimum & Maximum & Mean & Median & $\begin{array}{l}\text { Standard } \\
\text { deviation }\end{array}$ \\
\hline Leverage & $\begin{array}{l}\text { Total liabilities } \\
\text { divided by total } \\
\text { assets (in \%) }\end{array}$ & 0.5 & 400.58 & 58.12 & 56.95 & 37.07 \\
\hline $\begin{array}{l}\text { Composition } \\
\text { of board }\end{array}$ & $\begin{array}{l}\text { Percentage of } \\
\text { independent } \\
\text { commissioners } \\
\text { in the board }\end{array}$ & 20 & 100 & 43.55 & 40 & 13.41 \\
\hline $\begin{array}{l}\text { Company } \\
\text { size }\end{array}$ & $\begin{array}{l}\text { Total assets (in } \\
\text { million Rupiah) }\end{array}$ & 566.67 & $319,085,590.00$ & $10,017,110.00$ & $1,349,719.00$ & $33,298,746.44$ \\
\hline $\begin{array}{l}\text { Economic } \\
\text { performance }\end{array}$ & $\begin{array}{l}\text { Return on Assets } \\
\text { (ROA) - } 2 \text { year } \\
\text { average (in } \%)\end{array}$ & -200.2 & 42.02 & 3.92 & 2.91 & 15.68 \\
\hline $\begin{array}{l}\text { Age of } \\
\text { business }\end{array}$ & $\begin{array}{l}\text { Number of years } \\
\text { from inception }\end{array}$ & 3 & 148 & 28 & 24 & 19 \\
\hline \multicolumn{7}{|c|}{ Panel B: Categorical variables } \\
\hline Variable & \multicolumn{4}{|c|}{ Measurement } & Frequency & Percentage \\
\hline \multirow{2}{*}{$\begin{array}{l}\text { Government } \\
\text { ownership }\end{array}$} & \multicolumn{4}{|c|}{$1=$ there is a proportion of government ownership } & 20 & 9.0 \\
\hline & \multicolumn{4}{|l|}{$0=$ otherwise } & 203 & 91.0 \\
\hline Industry type & \multicolumn{4}{|c|}{$1=$ high profile industry } & $\begin{array}{r}99 \\
124\end{array}$ & $\begin{array}{l}44.4 \\
55.6\end{array}$ \\
\hline \multirow[t]{2}{*}{$\begin{array}{l}\text { International } \\
\text { operations }\end{array}$} & \multicolumn{4}{|c|}{$\begin{aligned} 1=\text { Yes-Have foreign sales or a foreign subsidiary or a } \\
\\
\text { foreign branch office }\end{aligned}$} & 79 & 35.4 \\
\hline & \multicolumn{4}{|c|}{$\begin{aligned} 0= & \text { No foreign sales, foreign subsidiaries or foreign } \\
& \text { Branch offices }\end{aligned}$} & 144 & 64.6 \\
\hline \multirow{2}{*}{$\begin{array}{l}\text { Explicit and } \\
\text { clearly stated } \\
\text { goal related to } \\
\text { the sustainable } \\
\text { value of } \\
\text { employees }\end{array}$} & \multicolumn{4}{|c|}{$\begin{array}{c}1=\text { the company has goals/missions related to } \\
\text { sustainable value of its employees }\end{array}$} & & \\
\hline & \multicolumn{4}{|l|}{$0=$ otherwise } & 105 & 47.1 \\
\hline
\end{tabular}

Source: Original table

Table III Descriptive statistics of voluntary Labour Practices and Decent Work Disclosure (LPDWD) practices

\begin{tabular}{lccccc}
\hline \multicolumn{1}{c}{ Dependent variable } & $\begin{array}{c}\text { Minimum } \\
(\%)\end{array}$ & $\begin{array}{c}\text { Maximum } \\
(\%)\end{array}$ & $\begin{array}{c}\text { Mean } \\
(\%)\end{array}$ & $\begin{array}{c}\text { Median } \\
(\%)\end{array}$ & $\begin{array}{c}\text { Standard } \\
\text { deviation }(\%)\end{array}$ \\
\hline $\begin{array}{l}\text { LPDWD index (\%) of } \\
\text { all } 223 \text { companies }\end{array}$ & 0 & 92.31 & 17.7 & 15.38 & 11.56 \\
$\begin{array}{l}\text { LPDWD index (\%) of } \\
\text { 204 disclosing } \\
\text { companies }\end{array}$ & 7.69 & 92.31 & 19.38 & 15.38 & 10.67 \\
\hline
\end{tabular}


Source: Original table

Table IV Results of multiple regression

\begin{tabular}{lccc}
\hline \multicolumn{1}{c}{ Variable } & Predicted Sign & Coefficient & $P$-value \\
\hline (Constant) & + & -0.02 & 0.792 \\
Leverage & + & -0.001 & 0.933 \\
Government ownership & + & 0.075 & $0.000^{* * *}$ \\
Industry type & + & 0.003 & 0.786 \\
International operations & + & 0.083 & $0.000^{* * *}$ \\
Explicit and clearly stated goal related to the & & 0.007 & 0.469 \\
sustainable value of employees & + & & 0.908 \\
Independence of board & + & 0.002 & $0.052^{*}$ \\
Company size (control variable) & + & 0.006 & 0.613 \\
Economic performance (control variable) & + & 0.036 & 0.593 \\
Age of business (control variable) & & 0.005 & \\
\hline Model summary & & & \\
\hline Adjusted R-Square & & 0.384 & \\
Standard Error of the Estimate & & 0.07374 & \\
Regression Model (Sig.) & & $0.000^{* * *}$ & \\
\hline Source: Original tabl & & \\
\hline
\end{tabular}

Source: Original table

*** significant at $1 \%$ level

** significant at $5 \%$ level

*significant at $10 \%$ level 
Figure I The 13 items of voluntary Labour Practices and Decent Work Disclosures (LPDWD)

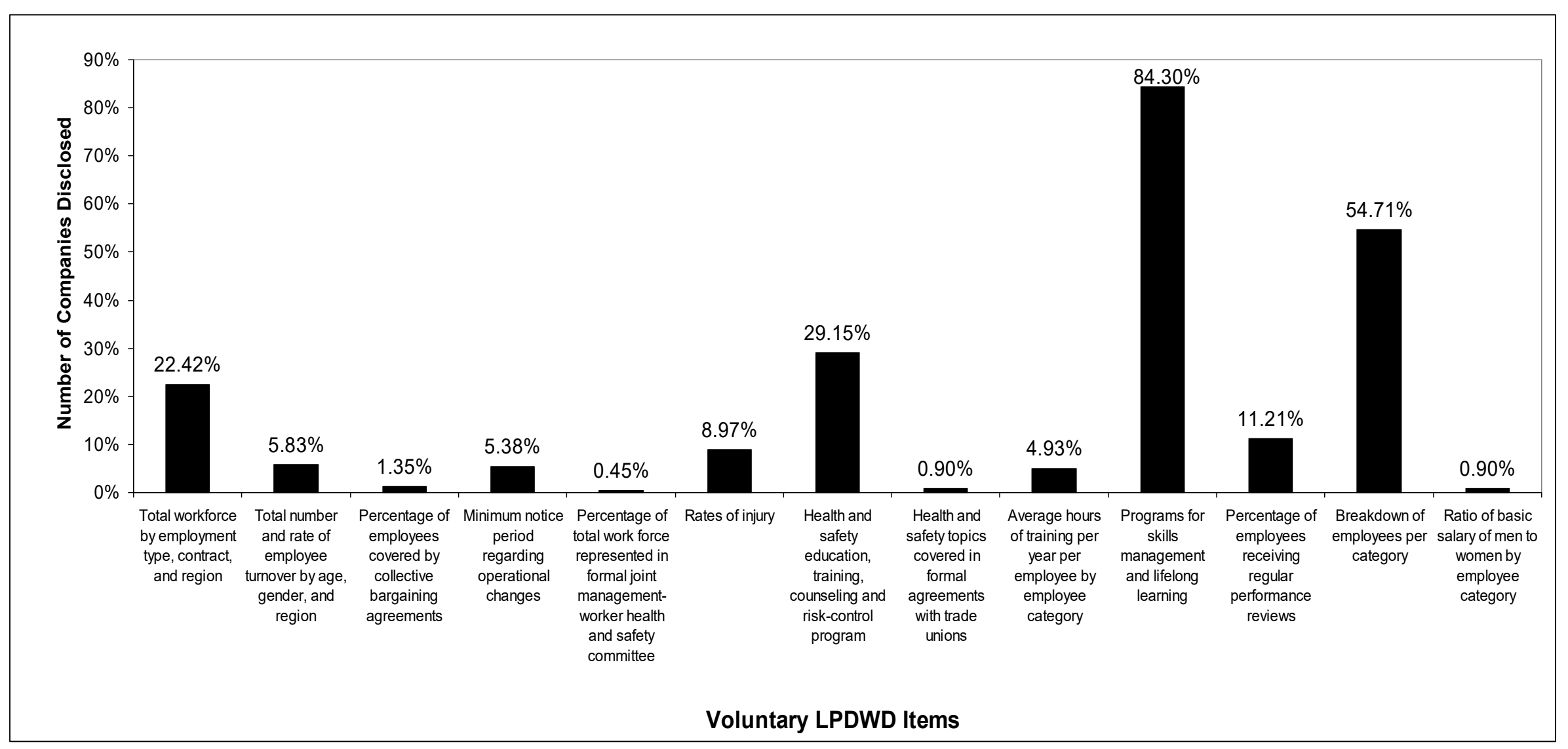

Source: Original figure 